DOI: 10.1515/ausp-2015-0034

\title{
Orpheus in the Underground
}

\section{Descents to the Underworld in $20^{\text {th }}$-Century and Contemporary Literature}

\author{
Dániel PUSKÁS \\ University of Szeged (Hungary) \\ Department of Comparative Literature Studies \\ dpuskas34@gmail.com
}

\begin{abstract}
In my study I deal with descents to the underworld and hell in literature in the $20^{\text {th }}$ century and in contemporary literature. I will focus on modern literary reinterpretations of the myth of Orpheus, starting with Rilke's Orpheus. Eurydice. Hermes. In Seamus Heaney's The Underground, in the Hungarian István Baka's Descending to the Underground of Moscow and in Czesław Miłosz's Orpheus and Eurydice underworld appears as underground, similarly to the contemporary Hungarian János Térey's play entitled Jeramiah, where underground will also be a metaphorical underworld which is populated with the ghosts of the famous deceased people of Debrecen, and finally, in Péter Kárpáti's Everywoman the grave of the final scene of the medieval Everyman will be replaced with a contemporary underground station. I analyse how an underground station could be parallel with the underworld and I deal with the role of musicality and sounds in the literary works based on the myth of Orpheus.
\end{abstract}

Keywords: descent, underworld, underground, Orpheus

\section{Introduction}

“A sequel to Dante's Divine Comedy: The modern hero retraces his steps from heaven to hell."

Charles Simic: The Monster Loves His Labyrinth (Simic 2008, 78)

The title of my study comes from Offenbach's famous operetta entitled Orpheus in the Underworld. In my paper I am going to deal with descents to the underground and hell in $20^{\text {th }}$-century literature until nowadays, and among these literary works I will focus on literary rewritings of the myth of Orpheus. 
Among the several literary works based on the motif of Orpheus I would like to analyse only a few poems: Rilke’s Orpheus. Eurydice. Hermes, Czesław Miłosz's Orpheus and Eurydice, Seamus Heaney's The Underground and István Baka's Descending to Underground of Moscow ${ }^{1}$ from the cycle entitled Stepan Pehotny's Testament. When I selected these particular literary works, I was interested in those poems where the underworld was replaced with an underground station.

In the ancient times scenes of descents to the underworld were very distant, far away places, like in Homer's Odyssey and Virgil's Aeneid, which were only accessible for privileged people who could go there through dangerous adventures where they risked their lives, or through ecstasy, like the Er of Pamphylia in Plato's Republic or Dante in medieval times. Sándor V. Kovács claims that in the Middle Ages descents could be divided into two patterns: into a religious and a secular one. Clerics did not tempt God, so only their souls were carried away to the other world from where they could return to earth by the grace of God, but secular knights and noblemen descended in a physical way to achieve secular triumph and reputation, or to prove their courage and power (V. Kovács 1985, 12-13). However, the cavaliers' physical descents to hell, either for a test of strength or for penitence, were done alone, like Orpheus's, thus, they could be compared to Orpheus in terms of self-interpretation and an inner journey. Descents are usually based on the pattern of death and resurrection. For instance, Plato's Er from Pamphylia had his vision in a state of pseudo-death, in Gilgamesh Ishtar (the goddess of fertility) descended to the underworld to visit her sister, Ereshkigal (the goddess of the underworld), who was frightened of her visitation and ordered her slaves to treat her sister as if she were dead, and the Hungarian visitors of St. Patrick's Purgatory also had a symbolic funeral before their descents to hell.

But as the centuries passed, hell got closer and closer, so in Rimbaud's Une Saison en Enfer (A Season in Hell, 1873) it turned into the narrator's inner journey. In Anouilh's Eurydice (1941) the descent took place at a railway station, but the person who is the modern equivalent of Hermes moved the play to psychological depth, while in T. S. Eliot's The Cocktail Party (1949) the descent of the myth of Alcestis was transferred to a psychological level, so Heracles, the powerful hero was replaced by a pshychologist.

Among the descents of the second half of the $20^{\text {th }}$ century Kurt Vonnegut's story collection entitled God Bless You, Dr. Kevorkian (1999) is worth mentioning, where the narrator - thanks to a treatment which was developed by the doctor mentioned in the title - is able to make odysseys to death where he interviews famous or notorius deceased people (e.g. Shakespeare, Newton, Hitler, Mary Shelley). ${ }^{2}$ The satirical tone of this collection reminds us of Lucian's Dialogues of

1 When I qoute this poem I use my own rough translation from Hungarian.

2 In the $29^{\text {th }}$ chapter of the first book of Vonnegut's Galápagos there is also a character called Richard who used to hire strange men to choke him until he lost consciousness, and he could 
the Dead. Glyn Maxwell in his verse novel entitled Time's Fool (2000) also made allusions to Dante and The Flying Dutchman. In his work a train turns into a metaphorical ghost train where the narrator meets a poet. In Philip Terry's Dante's Inferno (2014) the medieval story is transferred into a contemporary scene, and in Canto I Dante's visional ecstasy is replaced with the effects of drugs and alcohol. ${ }^{3}$ In my paper I will not deal with these works, but I think it is necessary to mention them because I wish to outline the context of these descents and I try to show how this literary tradition survives in contemporary literature.

\section{The Myth of Orpheus}

The myth of Orpheus does not need a detailed presentation, but there are a few points in the myth that I would like to specify. As regards the issue of shades, Roland Barthes's thought is worth mentioning; he described the withdrawn lover with the term fading: "Like a kind of melancholy image, the other withdraws into infinity and I wear myself out trying to get there" (Barthes 1990, 112). She becomes a living person without contour in the realm of Shades like Ulysses's mother, when he visited her in the underworld and he could not hug her no matter how hard he tried to (Barthes 1990, 113).

The character of Orpheus is a bit ambivalent, because in Plato's Symposium he was too cowardly to die for his lover (like Alcestis did), so the gods gave him only the image of his wife, but he could not get even her image (Plato 1951, 43-44). ${ }^{4}$ But Károly Kerényi claims that Orpheus brought his name into repute with a daring descent into the underworld alone, so his act of heroism raised him among the great mythical heroes such as Perseus, Heracles, Theseus and Jason (Kerényi 1977, 365). ${ }^{5}$

take short odysseys to death with this method. In this chapter there is a brief description of what this odyssey looks like.

3 "Halfway trough a bad trip / I found myself in this stinking car park, / Underground, miles from Amarillo" (Terry 2014, 22)

There is a very interesting parallel with Dante's Divine Comedy, because trip in this context means that someone is under the influence of drugs, but trip could be read as a reference to pilgrimage and the author utilized the similarity of ecstasy and the name of a drug.

4 Károly Kerényi claims that according to that version of the myth which survived, Orpheus's story began in Thessaly, where Heracles had already brought back Alcestis from among the dead (Kerényi 1977, 367). But in Ovid's work Orpheus was a strong-minded character who could negotiate with gods, he said if they would not give him back his wife, he would not like to live any longer: "if the Fates / Will not reprive her, my resolve is clear / Not to return: may two deaths give you cheer" (Ovid 1998, 226) (X. 39-41).

5 In Lucian's Menippus the protagonist has a comic appearance: he wears a cap, lion skin and he brings a lyre with him during his descent because he wants to take after the famous descenders: Ulysses, Heracles and Orpheus. 


\title{
Modern Rewritings of Orpheus and the Underground
}

\author{
"The apparition of these faces in the crowd; \\ Petals on a wet, black bough."
}

Ezra Pound: In a Station of the Metro (Pound 2007, 66)

David Ashford published a volume of studies entitled London Underground (2013), pointing at the importance of the underground in literature and culture, including popular culture. In the context of the underground, Ashford uses the term 'uncanny' (hinting at its German equivalent, unheimlich). He quotes Roger Luckhurst saying that "only ghosts, after all, can walk through walls, breach the boundaries of the increasingly privatized zone of the city, and shimmer impossibly between past and present Londons” (Ashford 2008).

The Underground is one of the earliest modern spaces and it is a perfect symbol of urban alienation; but it is also one of the places which have a huge myth-making potential (Ashford 2008). He claims that our condition in the underground is like a ghost in the machine and we feel that "we haunt rather than inhabit the modern city" (Ashford 2008). The shades of several deceased people who have just arrived in the underworld are compared to the stream of the faceless crowd in an underground station. ${ }^{6}$ In Virgil's Aeneid the underworld is paralleled with a station of public transport, because Charon is the ferryman of the river of the underworld who can take the shades of the several deceased people to the other side of the river. Virgil wrote: "The whole throng of / the dead was rushing to this part of the bank, mothers, men, / great-hearted heroes whose lives were ended, boys, unmarried / girls and young men laid on the pyre before the faces of their / parents [...] / There they stood begging to / be allowed to be the first to cross and stretching out their arms / in longing for the shore" (Virgil 2003, 213). ${ }^{7}$

In István Baka's poem the whole underground of Moscow is mythicized: the escalator is the tongue of Charybdis, the entrance of the hall is the mouth of Scylla, the trolley buses are Charon's boats, the five-kopeks are obols, and the ticket collector is Cerberus in Stepan Pehotny's vision. In his work the motif

6 In Homer's Odyssey we can read: "I took the victims, over the trench I cut their throats / and the dark blood flowed in - and up out of Erebus they came, / flocking toward me now, the ghosts of the dead and gone... / Brides and unwed youths and old men who have suffered much / and girls with their tender hearts freshly scarred by sorrow / and great armies of battle dead, stabbed by bronze spears, / men of war still wrapped in bloody armor - thousands / swarming around the trench from every side - / unearthly cries - blanching terror gripped me!" (Homer 2002: 254. XI. 40-48). In the inserted story entitled The Myth of Er in the tenth book of Plato's The Republic we can read: "He [the Er from Pamphylia] said that when his soul left his body it travelled in company of many others till they came to a wonderfully strange place, where there were close to each other, two gasping chasms in the earth, and opposite and above them two other chasms in the sky" (Plato 1987: 448. X. 614c).

$7 \quad$ VI. $305-309 ; 312-314$ 
of concentricity is very important: "the train goes on / Through the circles of stations / Like an infernal Mobius-loop / The track circulates underground aboveground / And it is closed into the tricky inner infinity / It could go nowhere except to itself" (Baka 2003, 283). ${ }^{8}$ In this poem the underworld is depicted as a living and pulsing organism, which could be compared to Lőrinc Szabó's poem entitled Grand Hotel Miramonti, where the hotel mentioned in the title is like a vegetal or animal organism. In his study Ashford quotes from Rod Menhgam's End of the Line as a motto: "At every Underground stop, people climb to the surface, emerge into the light of day, but the train goes on, circulation continues, the Circle Line ${ }^{9}$ providing a visual and conceptual magnet for the way the city stays alive by pumping flows of energy around the system" (Ashford 2008).

It is a significant difference that in Rilke's and Heaney's poems the underworld is empty and uninhabited. Rilke also intensifies emptiness with overwhelming silence, so there is almost no sound or voice coming from Eurydice or Hermes, who were walking behind Orpheus (Hermes only said a sentence in the end: "Er hat sich umgewendet" ("He has turned around"), ${ }^{10}$ and after it Eurydice only asked a word: "Wer?" (“Who?") [Rilke 1980, 301]). The two characters following Orpheus are depicted as mute people almost in the whole poem by Rilke's narrator: "Wie stille Silbererze gingen sie / als Aldern durch sein Dunkel” (Rilke 1980, 298);11 "Sie kämen doch, nur wärens zwei / die furchtbar leise gingen" (Rilke 1980, 299)12 and "müßte er sie sehen, / die beiden Leisen, die ihm schweigend nachgehn" (Rilke 1980, 299) (the italics in the German quotes are all my emphases - D. P.). ${ }^{13}$

In Rilke's poem it is difficult to detect Orpheus's uncertainty whether his wife is following him or not, so Miłosz in his work expresses it with sounds, rythm and non-instrumental music. The descent is also accompanied by music according to the myth: "For his defense he had a nine-string lyre. / He carried in it music of the earth, against the abyss / That buries all the sounds in silence. / He submitted to the music, yielded / To the dictations of a song, listening with rapt attention, / Became, like his lyre, its instrument" (Miłosz 2010). Furthermore, in Miłosz’s poem the persona talks about the song played for Persephone, so this song represents vocal music with instrumental accompaniment. But when Orpheus leaves the underworld, the power of music fails, or as the text says: "he was, now,

8 In Hungarian: “a metró szalad / Az állomások bugyrai között / Mint pokolbéli Möbius-szalag / Sínpár kering föld mélyén föld fölött / S fortélyos belső végtelenbe zárva / Nem futhat máshová csak önmagába”.

This poem can also be read on the Internet in Hungarian: http://www.baka.hu/alaszallas-amoszkvai-metroba-1142 (22 Apr. 2015) The structure of this poem is also circular, with repeating and varying the first line in the following stanzas.

$9 \quad$ It is an underground line in London. $-D$. $P$.

10 When I qoute Rilke's poem in English I resort to Stephen Mitchell's translation.

11 "Like veins of silent ore they silently / moved through its massive darkness"

12 "They had to be behind him, but their steps / were ominously soft."

13 "then he could not fail to see them, / those other two, who followed him so softly" 
like every other mortal. / His lyre was silent, yet he dreamed, defenseless" (Miłosz 2010), because in Ovid's Orpheus and Eurydice he was able to bring the whole underworld to a stop for a short time with his singing and playing the lyre. ${ }^{14}$ Only the rythm of the sounds of their steps makes evidence of Eurydice and Hermes following him: "And so they set out. He first, and then, not right away, / The slap of the god's sandals and the light patter / Of her feet fettered by her robe, as if by a shroud" (Miłosz 2010). Like Rilke's Orpheus, he can only trust his hearing to sense them, and it seems that they just follow him as an echo, i. e. only in their acoustical capacity, so the question arises whether they are really following him or he just hears the echo of his own footsteps. In the text there is nothing to support this idea, but we cannot prove the opposite either: "He would stop and listen. But then / They stopped, too, and the echo faded. / And when he began to walk the double tapping commenced again. / Sometimes it seemed closer, sometimes more distant" (Miłosz 2010). Furthermore, when the exit of the underworld became visible with the first blushes of dawn, there was nobody behind him and he could get no solace compared to Rilke's Orpheus, because at least he could see the hardly recognisable shape of his wife going back to the underworld. ${ }^{15}$

Seamus Heaney's work based on the motif of Orpheus is the first poem of his collection entitled Station Island (1984). The title of this book refers to a famous Irish place of pilgrimage ${ }^{16}-$ it is the location of St. Patrick's Purgatory, where many cavaliers descended (e.g. Lőrinc Tar from Hungary). ${ }^{17}$ In the cycle which comes from the title of this book there are references to Orpheus and in unit VI the narrator quotes Dante during his pilgrimage, but his pilgrimage is an interior one.

Heaney's poem The Underground is not only a rewriting of the myth of Orpheus - motifs from other myths and folk tales can also be traced in it. In the opening image, there is a newly wed couple running in the underground, the woman runs ahead, so it is reminiscent of the story of Apollo and Daphne ("me then like a fleet god gaining / Upon you before you turned to a reed") (Heaney 1985b, 13), followed

14 "So to the music of his string he sang, / And all the bloodless spirits wept to hear; / And Tantalus forgot the fleeing water, / Ixion's wheel was tranced; the Danaids / Laid down their urns; the vultures left their feast, / And Sisyphus sat rapt upon his stone. / Then first by that sad singing overwhelmed, / The Furies' cheeks, it's said, were wet with tears; / And Hades' queen and he whose sceptre rules / The Underworld could not deny the prayer, / And called Eurydice” (Ovid 1998: 226. X. 42-52).

15 "It happened as he expected. He turned his head / And behind him on the path was no one" (Miłosz 2010). Cf. Rilke’s version, where Orpheus could see: "der Gestallt zu folgen” (“[Hermes] silently turned to follow the small figure" (Rilke 1980, 301)).

16 You can read more about it in Michael Thurston's book entitled The Underworld in Twentieth Century Poetry: From Pound and Eliot to Heaney and Walcott $(2009,161)$.

17 In the jacket illustration of the American edition of the book we can see Sir John Lavery's picture entitled St. Patrick's Purgatory. This edition was published in 1985 by Farrar Straus Giroux. I use this edition when I qoute from the collection.

Seamus Heaney. 1985. Station Island, New York: Farrar Straus Giroux. For the jacket illustration: http://www.amazon.com/Station-Island-Seamus-Heaney/dp/0374519358 (22 Apr. 2015) 
by a reference to the tale of Hansel and Gretel, while the motif of Orpheus appears only in the final stanza: "the wet track / Bared and tensed as I am, all attention / For your step following and damned if I look back" (Heaney 1985b, 13). There are some acoustic references, too: "Honeymooning, moonlighting, late for the Proms, ${ }^{18}$ / Our echoes die in that corridor" (Heaney 1985b, 13).

In the title of this book the word station refers to Jesus Christ's Calvary (The Stations of the Cross), but it can also refer to an underground station. In contemporary Hungarian literature, in Péter Kárpáti’s play entitled Everywoman (which is inspired by the medieval Everyman but set in Budapest at the end of the $20^{\text {th }}$ century) the grave scene of the medieval play is set in the underground station "Astoria" where the allegorical characters are played by homeless people (who were former characters of the play). The dying medieval protagonist can be compared to the stations of Christ's Calvary, and there was a staging directed by Radu Afrim at the Tamási Áron Theatre in Sfântu Gheorghe/Sepsiszentgyörgy in 2013 , where the stage was an underground station and the scenes of the play could be read on the wall like the stations of an underground line. In Kárpáti's play there is a short scene of Danse Macabre during the underground scene where the character Skeleton tempts the protagonist to commit suicide. (However, in a later version published in 1999 she does not do it.) It recalls the Danse Macabre woodcuts from the $20^{\text {th }}$ century, for instance, Alfred Kubin's series entitled Ein neuer Totentanz (A New Danse Macabre) from 1947, where he transferred the medieval genre into a contemporary scene.

In 2009, in part III of János Térey's play entitled Jeremiah the underground station is also turned into a scene of the underworld, because in that unit several deceased people from Debrecen appear in the fictional underground station of Debrecen. There are men and women, adults and children who are telling the stories of their life and death after introducing themselves, this way reminding us of the Danse Macabre.

\title{
Conclusion
}

\author{
“Then I seemed to waken out of sleep \\ among more pilgrims whom I did not know \\ drifting to the hostel for the night."
}

Seamus Heaney: Station Island, VIII (Heaney 1985a, 83)

In my paper I analysed poems from the $20^{\text {th }}$ century which adopted the story of Orpheus's descent to the underworld: poems by Rainer Marie Rilke, Czesław

18 It is an eight-week summer season of daily orchestral classical music concerts which is usually held in Royal Albert Hall in London. - D. P. 
Miłosz, Seamus Heaney and István Baka, and of course, this list could be continued with many other interesting texts (for instance, with Carol Ann Duffy's Eurydice in her famous collection of poems entitled The World's Wife (1999)), but I was chiefly interested in literary works based on the motif of Orpheus where the underworld is replaced with the underground.

David Ashford's book, London Underground, points out that the underground has become one of the most important spaces of modern cities, so it has an effect on culture and literature as well, and he claims that "the London Underground is a prominent symbol of urban alienation" (Ashford 2008), which is a bit similar to the apathy of the dead people in the ancient Greek and Roman descents underground (e. g. in Homer's Odyssey and Virgil's Aeneid). In Rilke's poem Eurydice is also alienated from life and worldly things: "Sie war in sich, wie Eine hoher Hoffnung, / und dachte nicht des Mannes, der voranging, / und nicht des Weges, der ins Leben aufstieg. / Sie war in sich. Und ihr Gestorbsein / erfüllte sie wie Fülle" (Rilke 1980, 300). ${ }^{19}$ The underground also has a huge myth-making potential (Ashford 2008), and the analysed literary works, Heaney's, Miłosz's and Baka's poems respectively, benefitted from it and they mixed ancient and medieval motifs with modern patterns.

Although Rilke's poem is an exception among the texts which deal with representing the underground as the underworld, but in utilizing the role of sounds and music it has a great effect on the other literary works, for example, on Miłosz's and Heaney's poems, where the sound of footsteps is very important. In the myth of Orpheus there is a huge possibility of self-reflection, of meditating on the role and power of art (especially poetry and music). In $1937 \mathrm{~W}$. H. Auden also raised the question in his poem entitled Orpheus: "What does the song hope for? / [...] / To be bewildered and happy, / Or most of all the knowledge of life?” (Auden 1994, 158).

Orpheus could make miraculous things with his singing and playing the lyre:20 he could enchant wild beasts and even make the trees and rocks follow him and dance (Graves 1973, 111), ${ }^{21}$ and he could descend to the underworld and come back from there alive. It is not accidental that there are a lot of musical adaptations of the myth, for instance, Monteverdi's and Gluck's operas, Offenbach's operetta,

19 "She was deep within herself, like a woman heavy / with child, and did not see the man in front / or the path ascending steeply into life. / Deep within herself. Being dead / filled her beyond fulfilment."

She could not recognise even her husband: "Und als plötzlich jäh / der Gott sie anhielt und mit Schmerz im Ausruf / die Wörte spach: Er hat sich umgewendet -, / begriff sie nichts und sagte leise: Wer?" (Rilke 1980, 301). In English: “And when abruptly / the god put out his hand to stop her, saying, / with sorrow in his voice: He has turned around -, / she could not understand, and softly answered: Who?"

20 Cf. it with the myth of Zethus and Amphion. They founded Thebe with music: Amphion played the lyre and the stones glided into place (Graves 1973, 257).

21 He got his lyre from Apollo and the Muses taught him its use (Graves 1973, 111). 
Franz Liszt's symphonic poem and Stravinsky's ballet. In art Orpheus is one of the greatest survivors among mythical characters and the newer works of art still keep his myth alive.

\section{Works cited}

Ashford, David. 2008. The Ghost in the Machine: Psychogeography in the London Underground 1991-2007. The Literary London Journal vol. 6. no. 2. http://www. literarylondon.org/london-journal/september2008/ashford.html (21 Apr. 2015)

---. 2013. London Underground: A Cultural Geography. Liverpool: Liverpool UP. Auden, W[ystan] H[ugh]. 1994. Orpheus. In Collected Poems, ed., preface Edward Mendelson. London: Faber and Faber.

Baka, István. 2003. Alászállás a moszkvai metróba. [Descent into the Underground of Moscow.] In Versek [Poems], ed. and afterword Attila Bombitz. Szeged: Tiszatáj.

Barthes, Roland. 1990. Fade-out. In A Lover's Discourse: Fragments. Trans. Richard Howard. 112-116. Harmondsworth: Penguin.

Graves, Robert. 1973. The Greek Myths. Vol. 1. Harmondsworth: Penguin.

Heaney, Seamus. 1985a. Station Island. In Station Island. New York: Farrar Straus Giroux.

---. 1985b. The Underground. In Station Island. New York: Farrar Straus Giroux. Homer. 2002. The Odyssey. Trans. Robert Fagles, introduction, notes Bernard Knox. London: Penguin.

Kerényi Károly. 1977. Görög mitológia. [Greek Mythology.] Trans. Grácia Kerényi. Budapest: Gondolat.

Mahawatte, Royce. 2014. In Tunnels. The Times Literary Supplement February 28 no. 5787.

Miłosz, Czesław. Orpheus and Eurydice. Trans. Czesław Miłosz and Robert Hass. http://oriana-poetry.blogspot.hu/2010/11/milosz-as-orpheus.html (22 Apr. 2015)

Ovid. 1998. Orpheus and Eurydice. In Metamorphoses. Trans. A. D. Melville, introduction, notes E. J. Kenney. Oxford and New York: Oxford UP.

Plato. 1987. The Republic. Trans., introduction Desmond Lee. Harmondsworth: Penguin.

---. 1951. The Symposium. Trans. Walter Hamilton. Harmondsworth: Penguin.

Pound, Ezra. 2007. In a Station of the Metro. In Conversation Pieces: Poems that Talk to Other Poems. Selected by Kurt Brown and Harold Schechter, foreword Billy Collins. New York, London and Toronto: Alfred A. Knopf.

Rilke, Rainer Maria. 1980. Orpheus. Eurydike. Hermes. In Werke: Gedicht-Zyklen

[Works: Poem Cycles], eds. Ruth Sieber and Ernst Zinn. Frankfurt am Main: Insel. 
Simic, Charles. 2008. The Monster Loves His Labyrinth: Notebooks. Keene NY: Ausable.

Terry, Philip. 2014. Inferno: Canto I. London Review of Books, vol. 36 no. 7. http:// www.lrb.co.uk/v36/n07/philip-terry/inferno-canto-i

Thurston, Michael. 2009. Seamus Heaney's "Station Island.” In The Underworld in Twentieth Century Poetry: From Pound and Eliot to Heaney and Walcott. New York: Palgrave Macmillan.

Virgil. 2003. Aeneid. Trans., introduction David West. London: Penguin.

V. Kovács, Sándor. 1985. Magyar pokoljárók: Egy fejezet lovagi irodalmunk történetéből. [Hungarian Descents into Hell: A Chapter from the History of Our Court Literature.] In Tar Lốrinc pokoljárása: Középkori magyar víziók [Lórinc Tar's Descent into Hell: Medieval Hungarian Visions], ed., publisher, foreword, notes S. V. K., trans. Ibolya Bellus et al. Budapest: Szépirodalmi. 